Metallophysics and Advanced Technologies

металофіз. новітні технол.

Metallofiz. Noveishie Tekhnol.

2021 , vol. 43, No. 5, pp. 673-688

https://doi.org/10.15407/mfint.43.05.0673

Reprints available directly from the publisher

PHYSICS OF STRENGTH AND PLASTICITY

PACS numbers: 61.66.Dk, 61.72.Mm, 62.20.fg, 62.20.M-, 81.40.-z, 81.40.Lm

\title{
Effect of Grain Size and Deformation Temperature on Mechanical Properties and Failure Behaviour of 316L Austenitic Stainless Steel
}

\author{
Halil Katiksiz and Süleyman Gündüz
}

\author{
Karabük University, \\ Technology Faculty, Department of Manufacturing Engineering, \\ 78050 Karabük, Turkey
}

In this work, the effects of grain size and deformation temperature on mechanical properties and failure behaviour of $316 \mathrm{~L}$ austenitic stainless steel (ASS) are investigated. The cold, warm and hot deformation are carried out at temperatures of 25,500 , and $800^{\circ} \mathrm{C}$ for the strain rate of $1 \cdot 10^{-3} \mathrm{~s}^{-1}$. The results show that strength and workhardening index of all samples decrease with increasing test temperature; however, decrement in strength and workhardening index is more less in coarse grained samples compared to the finer grained samples. This is due to dynamic strain ageing (DSA) occurred in the coarse grained samples which showed more pronounced serrated behaviour after testing at 500 or $800^{\circ} \mathrm{C}$ due to interaction of mobile dislocations and solute atoms.

Key words: metals and alloys, quenching, precipitation, diffusion, metallography.

У цій роботі досліджено вплив розміру зерен та температури деформації на механічні властивості та поведінку руйнування аустенітної нержавіючої сталі 316L (ASS). Холодна, тепла та гаряча деформації проводились за температур 25, 500 та $800^{\circ} \mathrm{C}$ при швидкості деформації $1 \cdot 10^{-3} \mathrm{c}^{-1}$. Результати показали, що міцність та показник деформаційного зміцнення всіх зразків зменшуються із збільшенням температури випробовування, однак зменшення міцності та показника загартовування є меншими в грубозернистих зразках порівняно 3 дрібнозернистими зразками. Це

Corresponding author: Süleyman Gündüz

E-mail: sgunduz@karabuk.edu.tr

Citation: Halil Katiksiz and Süleyman Gündüz, Effect of Grain Size and Deformation Temperature on Mechanical Properties and Failure Behaviour of 316L Austenitic Stainless Steel, Metallofiz. Noveishie Tekhnol., 43, No. 5: 673-688(2021), DOI: $10.15407 /$ mfint.43.05.0673. 
пов'язано з динамічним деформаційним старінням (DSA), що відбулося в грубозернистих зразках, які виявили більш виражену зубчасту поведінку після випробувань за температури 500 або $800^{\circ} \mathrm{C}$ завдяки взаємодії рухомих дислокацій та розчинених атомів.

Ключові слова: метали та стопи, гартування, преципітація, дифузія, металографія.

(Received September 8, 2020; in final version, March 12, 2021)

\section{INTRODUCTION}

Austenitic stainless steel (ASS) have an important place among the stainless steel commonly used in different fields of industry because of its corrosion resistance, high temperature resistivity and good weldability [1-3]. This steel also shows high workhardening rate during deformation. Therefore, different deformation mechanisms can be activated and improve the mechanical properties by the introduction of dislocation and deformation induced martensite [4-6]. However, the workhardening always occurs during cold deformation. Nevertheless, the martensitic transformation due to deformation can increase the workhardening rate [7].

ASS cannot be hardened by heat treatments. Due to the austenite structure at room temperature and high temperatures, these steels do not show any phase transformation and therefore do not harden by heat treatment. As a result, different techniques such as grain refining, solid solution strengthening, and cold working accompanied by deformation induced martensitic transformation have been used to strengthen these alloys [8-14]. However, literature studies indicated that although the effects of the grain refining, solid solution strengthening and workhardening on the room temperature mechanical properties have been clarified, the influence of these strengthening mechanisms on elevated temperature mechanical properties have not been investigated in detail. As is known one of the methods controlling the properties of steel is the grain refinement. The number of grains increases by reducing the grain size and, thus the amount of grain boundaries increases. Any dislocation increases the strength of the steel by moving just a short distance before encountering a grain boundary. Hall-Petch equation reveals the relationship between grain size and yield strength [15]. Small grain size increases the strength and toughness of the steel at room temperature, however it decreases the strength and toughness at elevated temperatures.

Also, DSA in ASS appears to occur in the austenite phase at elevated temperatures depending on the strain rates. As found, the activation energy of DSA in the ASS process was nearly as equal to the activation energy of $\mathrm{C}$ and $\mathrm{N}$ diffusion in the austenite phase [16]. DSA is the in- 
teraction between moving dislocations and solute atoms during plastic deformation and is believed to reduce the ductility of the material. However, in this study, some alloys showed an increase in the ductility stage during the DSA of ASS. One possible explanation was the formation of twins in ASS. In the ASS strain-ageing process, twisting occurs in some compositions when dislocation motion ceases or is limited by solute atoms. This is known to cause the formation of each twin that lead to some sheared strain in the lattice [17].

Over the past 60 years the effect of grain sizes and DSA on mechanical properties of different alloys has been studied. Although these studies have shown the effects of grain sizes and DSA on mechanical properties, much work should be done before a full understanding is reached. The aim of the present work is, therefore, to find out how mechanical properties of $316 \mathrm{~L}$ ASS are affected by plastic deformation depending on different grain sizes and testing temperatures. On the other hand, interpretation of the fracture mechanism can provide valuable information about the cause of failure.

\section{EXPERIMENTAL PROCEDURE}

316L ASS with chemical composition given in Table 1 was used in the present experimental study. 2 pieces of $316 \mathrm{~L}$ ASS were commercially supplied with $\varnothing 20 \mathrm{~mm}$ diameter and $1000 \mathrm{~mm}$ length. 24 samples of $\varnothing 20 \times 70 \mathrm{~mm}$ were cut from this steel in order to use them in the asreceived and heat treated conditions which were applied to form different grain size. Samples in the dimension of $\varnothing 20 \times 70 \mathrm{~mm}$ except to those in the as-received conditions were heat treated at $1100^{\circ} \mathrm{C}$ for $60 \mathrm{~min}$ (HT60), 160 min (HT160) and 260 min (HT260) and then quenched in the cold water. Tensile test samples obtained from as-received and heat treated samples were prepared according to TS EN ISO 6892-2 standard after facing turning, straight turning precision longitudinal machining and threading operations on the lathe, respectively. Tensile test samples were then subjected to cold, warm and hot tensile deformation at 25, 500 , and $800^{\circ} \mathrm{C}$ with a strain rate of $1 \cdot 10^{-3} \mathrm{~s}^{-1}$ using MTS $(100 \mathrm{kN}$ Servohydraulic Test Device). In this process, a total of 6 test samples, 2 for each test temperature, were used for one condition. Totally 24 test samples were used for as-received and heat treated conditions. After each test, maximum tensile strength, flow stress at 3\%, elongation and workhardening index $(n)$ were determined for each sample subjected to tensile test at different temperatures. To calculate the workhardening

TABLE 1. Chemical composition of 316L ASS.

\begin{tabular}{c|c|c|c|c|c|c|c|c|c|c}
\hline Elements & $\mathrm{C}$ & $\mathrm{Si}$ & $\mathrm{Mn}$ & $\mathrm{Ni}$ & $\mathrm{Cr}$ & $\mathrm{Mo}$ & $\mathrm{N}$ & $\mathrm{S}$ & $\mathrm{P}$ & $\mathrm{Fe}$ \\
\hline wt. $\%$ & $\mathbf{0 . 0 2 4}$ & $\mathbf{0 . 3 8}$ & 1.30 & 10.10 & 16.57 & 2.03 & 0.041 & 0.004 & 0.029 & Bal. \\
\hline
\end{tabular}


index, true stress $\sigma$ and true strain $\varepsilon$ were determined for the region of uniform plastic deformation up to maximum load. The slope of the latter relationship defines the work hardening index $n$ [18].

Microstructural investigations were carried out using Nikon Epiphot brand optical microscope with a magnification capacity of X50-X1000; images were captured and analyzed by Clemex software. Changes in microstructure were examined by taking images at different magnifications from different regions of each sample. Samples prepared using conventional sample preparation methods were subjected to electrolytic etching in solution consisting of $89 \%$ pure water, $10 \%$ oxalic acid and 1\% nitric acid mixture. The electrolytic etching was carried out at room temperature using 15-20 V potential at 2 ampere current. In addition, the fracture surface examination of tensile samples was carried out using Carl Zeiss Ultra Plus Gemini FE-SEM brand scanning electron microscope (SEM). Microstructure and fracture surface of as-received and heat treated samples tested at different temperatures were compared with each other to determine the effect of different grain sizes on mechanical properties of 316L ASS. The measurement of grain size was done by intercepts along a test line oriented at $45^{\circ}$. At least 500 grains, cut by intersecting line, were counted for each sample. After counting the grains, the total length of the intersecting lines was divided by the number of grains cut by intersecting line to determine mean linear intercept grain size [18, 19].

\section{RESULTS AND DISCUSSION}

Microstructure of the as-received, HT60, HT160 and HT260 samples is seen in Figs. 1, $a-c$ and $d$, respectively. Table 2 also reveals measured mean linear intercept grain sizes of as-received, HT60, HT160 and HT260 samples. As is seen from Fig. 1 and Table 2 that all samples consist of austenite grains with different sizes. For example, austenite grain size was measured as $15 \mu \mathrm{m}$ in as-received sample and it increased to 22,28 and $36 \mu \mathrm{m}$ when the samples were austenitised at $1100^{\circ} \mathrm{C}$ for $60 \mathrm{~min}$ (HT60), $160 \mathrm{~min}$ (HT160) and $260 \mathrm{~min}$ (HT260) and then cooled in water, respectively.

This is an expected result because, atomic diffusion is rapid at high temperature, eventually, coarse grains result in the steel due to competitive growth of large grains against small grains. Grain growth involves the grain boundary movement and allows some grains to grow more than others. Diffusion of atoms across the grain boundary is required, and, consequently, the growth of the grains is related to the activation energy required for an atom to jump across the boundary. Low activation energies or high temperatures increase the grain sizes. Many heat treatments of metals, including holding time at high temperatures, must be controlled to prevent grain growth [15]. 

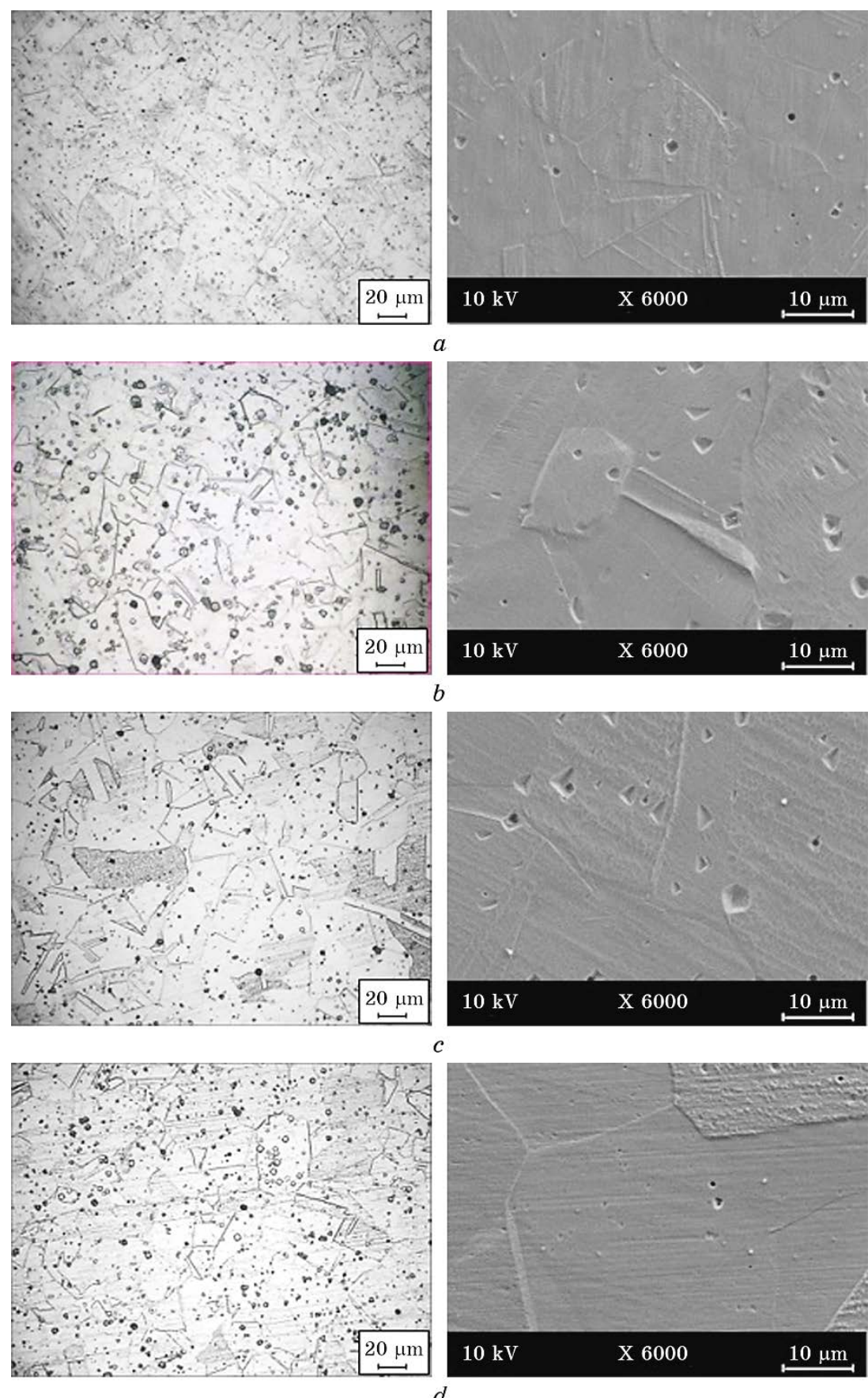

Fig. 1. Microstructure of 316L ASS: $a$-as-received, $b-\mathrm{HT} 60, c-\mathrm{HT} 160$, and $d-\mathrm{HT} 260$ conditions. 
The change in maximum tensile strength, flow stress at $3 \%$ and elongation values of as-received, HT60, HT160 and HT260 samples is shown in Fig. 2. The maximum tensile strength and flow stress at $3 \%$ of asreceived, HT60, HT160 and HT260 samples tested at a deformation rate of $1 \cdot 10^{-3} \mathrm{~s}^{-1}$ showed a continuous decrease with increasing test temperature from $25^{\circ} \mathrm{C}$ to $500^{\circ} \mathrm{C}$ and $800^{\circ} \mathrm{C}$. However, the decrease in strength values at $500^{\circ} \mathrm{C}$ is lower than at $800^{\circ} \mathrm{C}$ (see Fig. 2). The results of this study are similar to those of Muhamed et al. [20]. The authors investigated the DSA behaviour of 316L ASS and subjected the samples to a hot tensile test in the $25-800^{\circ} \mathrm{C}$ range. They found that the strength values decreased slightly in the range of $25-500^{\circ} \mathrm{C}$, but in the tensile test performed over $500^{\circ} \mathrm{C}$, the decrease in strength values accelerated. In addition, Taştemür and Gündüz [21] studied tensile properties of AISI H10 steel in the temperature range of $25-700^{\circ} \mathrm{C}$ under as-quenched conditions. The tensile properties showed an increase in YS and UTS of asquenched samples tested at 200 or $300^{\circ} \mathrm{C}$ consistent with DSA. Further increase in the testing temperature has decreased YS and UTS.

However, the elongation in 316L ASS falls gradually with increase in testing temperature to $500^{\circ} \mathrm{C}$ under as-received, HT60, HT160 and HT260 conditions. The tested samples showed the lowest ductility of $14 \%$ for as-received, $35 \%$ for HT60, 37\% for $\mathrm{HT} 160$ and $35 \%$ for HT260 test pieces. When the testing temperature increased to $800^{\circ} \mathrm{C}$, the elongation of the as-received, HT60, HT160 and HT260 samples also increased. Small variation in strength values and a decrement in elongation after testing at $500^{\circ} \mathrm{C}$ indicated that DSA occurred in $316 \mathrm{~L}$ ASS under as-received, HT60, HT160 and HT260 conditions. DSA generally takes place in steels due to the interactions between dislocations and solute atoms [22]. Gupta et al. [23] investigated microstructure and mechanical properties of $\mathrm{Cr}-\mathrm{Mo}-\mathrm{V}$ steels and showed that the elongation decreases when the testing temperature increases reaching minimum values at around $350-400^{\circ} \mathrm{C}$. However, elongation revealed an increment above $400^{\circ} \mathrm{C}$.

When the mechanical test results of as-received, HT60, HT160 and HT260 samples are compared with each other, it is seen that there are significant differences in mechanical properties. For example, room temper-

TABLE 2. Mean linear intercept grain sizes of as-received and heat treated samples.

\begin{tabular}{c|c}
\hline Samples & $\begin{array}{c}\text { Mean linear intercept grain sizes }(\mu \mathrm{m}) \pm \sigma(\text { stand- } \\
\text { ard deviation })\end{array}$ \\
\hline As-received & $15 \pm 0.47$ \\
HT60 & $22 \pm 0.69$ \\
HT160 & $28 \pm 0.87$ \\
HT260 & $36 \pm 1.12$ \\
\hline
\end{tabular}


ature test results indicated that the flow stress at 3\% of the as-received samples is $786 \mathrm{MPa}$, but it showed continuous decrement in the HT60, HT160 and HT260 to 412, 396, and $361 \mathrm{MPa}$, respectively.

The reason for this drop in flow stress at $3 \%$ is related to grain size
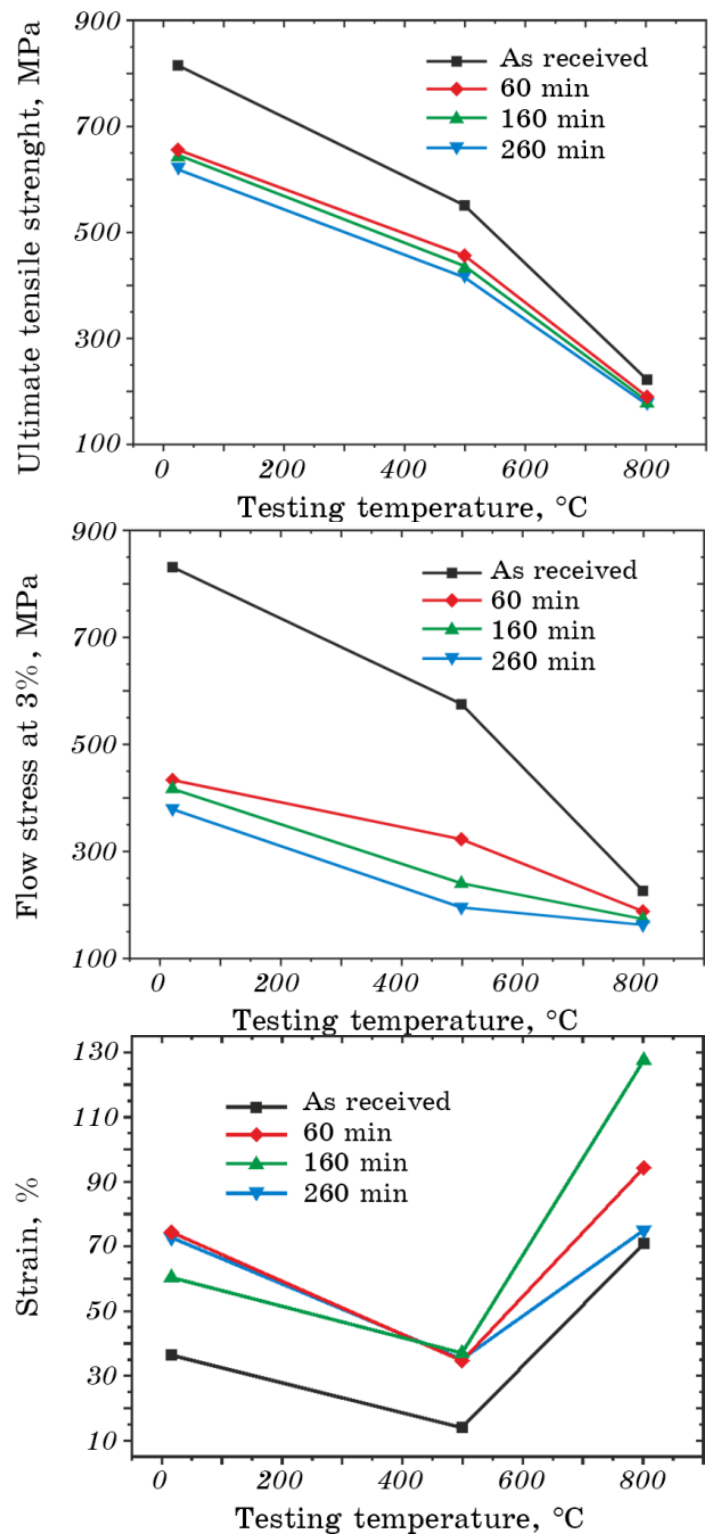

Fig. 2. Mechanical properties of as-received, HT60, HT160, and HT260 specimens tensile tested at 25,500 , and $800^{\circ} \mathrm{C}$. 
(see Fig. 2). Because, the grain boundary decreases with increasing the grain sizes and as a result, the dislocations move more easily, causing the strength values to decrease [24]. As it is known the grain sizes affect the mechanical properties of steel such as YS and hardness, the ductile-brittle transition temperature and susceptibility to environmental embrittlement according to Hall-Petch equation:

$$
\sigma_{y}=\sigma_{0}+k_{y} d^{-1 / 2},
$$

where $\sigma_{y}$ is the yield stress, $\sigma_{0}$ is a material constant, $k_{y}$ is a strengthening coefficient and $d$ is the average grain size. So, the smaller the grain size means the higher the strength. This happens due to the interactions between dislocations and grain boundaries which increase when the grain size is smaller [25]. Therefore, it is seen that flow stress at $3 \%$ decreases due to the increase in grain size of the samples. The effect of grain size on strength was found to be reduced by increasing the test temperature to 500 and $800^{\circ} \mathrm{C}$. As the grain boundary area decreases with increasing grain size, a large-grained material above the equicohesive temperature may have higher strength than the smallgrained one [26].

In addition, the workhardening index $(n)$ of as-received, HT60, HT160 and HT260 samples were calculated to determine the effect of grain size on workhardening and the occurrence of DSA. The increase in the workhardening index $(n)$ value is one of the most important parameters indicating that DSA occurs. Figure 3 shows the workhardening index $(n)$ of the as-received, HT60, HT160, and HT260 samples calculated based on testing temperatures. As shown in Fig. 3, the $n$ values of HT160 and HT260 samples increased with the increase in

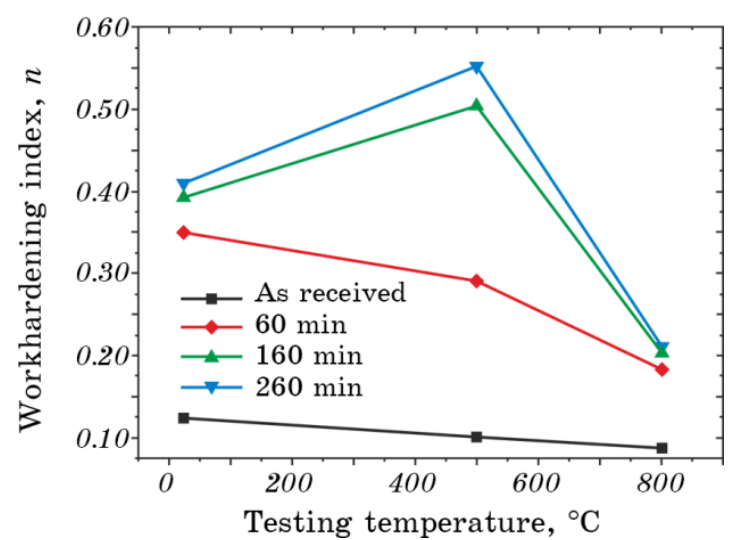

Fig. 3. Workhardening index values of as-received, HT60, HT160, and HT260 samples. 
testing temperature and reached its highest value at $500^{\circ} \mathrm{C}$. When the test temperature increased to $800^{\circ} \mathrm{C}$, the $n$ value decreased. However, the $n$ values of as-received and HT60 samples revealed a decrease compared to those of the room temperature value after testing at 500 and $800^{\circ} \mathrm{C}$. Deformation processes are divided into three groups as cold, warm and hot deformation according to the ratio of deformation temperature to metal melting temperature. If the ratio of deformation temperature to melting temperature is less than 0.3 , it is called cold deformation, between $0.3-0.5$ is warm deformation and if it is greater than 0.5 it is called hot deformation. In the present work, deformation at $800^{\circ} \mathrm{C}$ is higher than 0.5 , so it falls into hot deformation category. In the hot deformation process, deformation hardening and deformed grain structure are removed by the formation of new grains as a result of recrystallization formed during deformation [26]. Therefore, the $n$ values of the samples tested at $800^{\circ} \mathrm{C}$ were found to be low.

When the $n$ values of as-received, HT60, HT160 and HT260 samples were compared with each other, the $n$ value of the HT260 with the largest grain size of $36 \mu \mathrm{m}$ was found to be the highest for all test temperatures. It was observed that the $n$ values decreased with the decrease in grain size to $28 \mu \mathrm{m}$ (HT160), $22 \mu \mathrm{m}$ (HT60) and $15 \mu \mathrm{m}$ (asreceived). These results show that heat treated HT60, HT160 and HT260 samples are more affected by DSA than the as-received samples. Gündüz [27] studied the DSA of niobium microalloy steel under as-received, air and stainless steel tube cooled conditions. For this purpose, samples prepared for different conditions were tested in the temperature range of $25-450^{\circ} \mathrm{C}$. The results indicated that the workhardening index $(n)$ values increased in the temperature range of 200$400^{\circ} \mathrm{C}$ due to DSA.

The increase in $n$ values due to the increase in grain size can be attributed to the presence of more $\mathrm{C}$ or $\mathrm{Cr}$ atoms in the grain. The move-

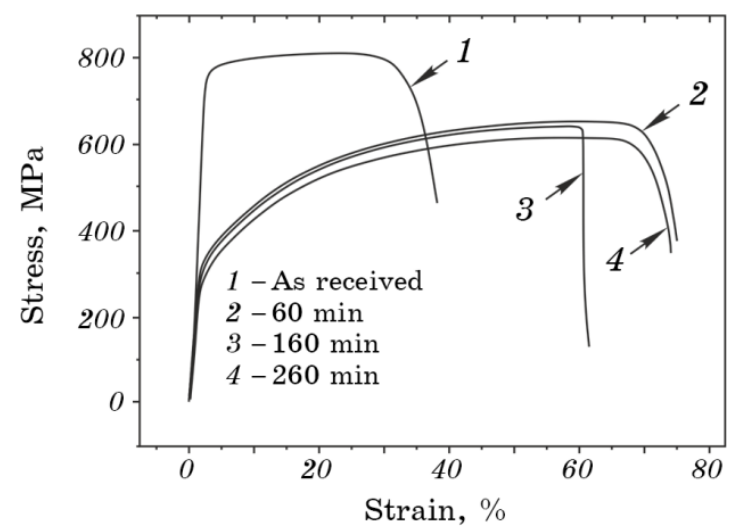

Fig. 4. Stress-strain diagrams for the samples tested at $25^{\circ} \mathrm{C}$. 
ment of dislocations was prevented more effectively by $\mathrm{C}$ or $\mathrm{Cr}$ atoms in the grain and $n$ values reached the highest values especially in coarse grained HT260 samples. Grain size significantly affects strain ageing hardening of steels [28]. In the present experiment work, the annealing time at $1100^{\circ} \mathrm{C}$ increased from 60 minutes to 160 and 260 minutes caused an increase in the grain size from $22 \mu \mathrm{m}$ to $28 \mu \mathrm{m}$ and $36 \mu \mathrm{m}$, respectively. The grain boundary is suitable place for the diffusion of interstitial or substitutional atoms [29]. Therefore, diffusion of $\mathrm{Cr}$ and $\mathrm{C}$ atoms to grain boundaries during the solution heat treatment reduces $\mathrm{Cr}$ and $\mathrm{C}$ concentration in the grain. As grain size increases, the concentration of $\mathrm{Cr}$ and $\mathrm{C}$ atoms diffusing to grain boundaries decreases due to increasing distance of which these atoms need to travel to reach the grain boundary for the fast diffusion. Similar results are seen in Alshalfan's study [30] who showed that higher amount of C atoms easily diffuse to the grain boundary due to small-grained structures provided a short diffusion distance between the interstitial atoms and the grain boundaries, As a result, as the grain size increases, the amount of the interstitial or substitutional atoms diffusing to the grain boundary decreases and a high concentration of the interstitial or substitutional atoms remain in the grain causing DSA. One of the most important indications of DSA is the presence of serrated behaviour in the homogeneous plastic deformation region of the stressstrain diagram.

Figures 4-6 show the stress-strain diagrams of as-received, HT60, $\mathrm{HT} 160$ and HT260 samples tested at 25,500 , and $800^{\circ} \mathrm{C}$. As is seen, the stress and strain diagrams obtained after testing at $25^{\circ} \mathrm{C}$, did not show any serrations, because $\mathrm{Cr}$ retards the $\mathrm{C}$ diffusion to dislocations at lower temperatures in 316L ASS [15]. However, serrated yielding was observed in all samples as the test temperature raised to $500^{\circ} \mathrm{C}$ or

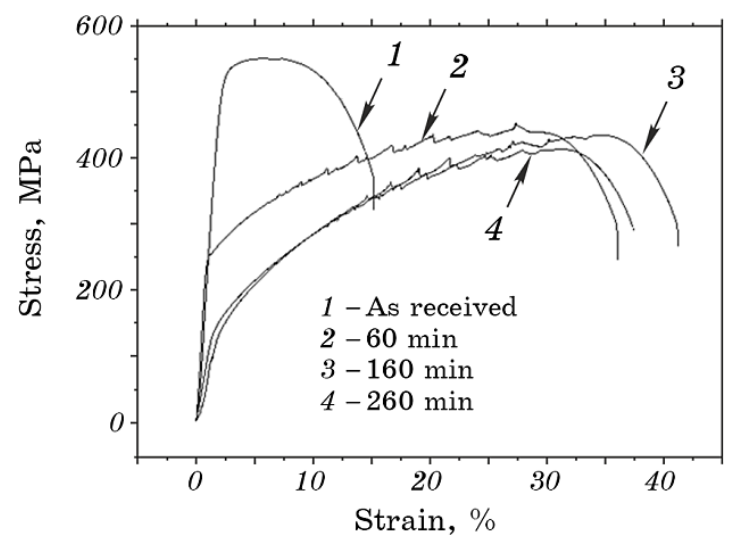

Fig. 5. Stress-strain diagrams for the samples tested at $500^{\circ} \mathrm{C}$. 
$800^{\circ} \mathrm{C}$ for the strain rate of $1 \cdot 10^{-3} \mathrm{~s}^{-1}$. The magnitude of the serrations decreased from the curves at $800^{\circ} \mathrm{C}$. DSA refers to the interactions between diffusing solute atoms and mobile dislocations. Buona et al. [31] calculated the activation energy as $\Delta H=126.7 \mathrm{~kJ} \cdot \mathrm{mol}^{-1}$ for strain ageing in AISI 430 stainless steel. This value is bigger than the activation energy for strain ageing in low carbon steels, $84.2 \mathrm{~kJ} \cdot \mathrm{mol}^{-1}$. However, it can be said that the affinity of $\mathrm{Cr}$ for $\mathrm{C}$ atoms changes the activation energy for diffusion of the latter in 316L ASS to such an extent. Thus, as-received and heat treated samples showed serrated behaviour at 500 and $800^{\circ} \mathrm{C}$, because $\mathrm{Cr}$ cannot retard the $\mathrm{C}$ diffusion to dislocations at higher temperatures in 316L ASS. Also, deformation rate and temperature affecting the solute atom diffusion and dislocation movement, play an important role in the event of DSA. The solute atom diffusion is slow compared to dislocation for the occurrence of DSA at a high strain rate and low temperature. However, solute atoms can move with the dislocations at a low strain rate and high temperature resulted of DSA disappear. Thus, DSA is seen at intermediate strain rates and temperatures [27, 32].

When the serrations behaviours of as-received, HT60, HT160 and HT260 samples are compared with each other, it was observed that HT60, HT160 and HT260 samples revealed more pronounced serrations compared to that of the as-received samples because of the higher amount of solute atoms in solution [33]. Dissolution of carbides occurs in the HT60, HT160 and HT260 samples heat treated at $1100^{\circ} \mathrm{C}$ for different times and then cooled in water results in higher amount of solute atoms in solution. It was indicated that strain ageing effects can approach their maxima at interstitial content of only about $0.002 \%$. The content of interstitial solute atoms in solution must be decreased to about $0.0001 \%(1 \mathrm{ppm})$ or less to eliminate the effects of strain age-

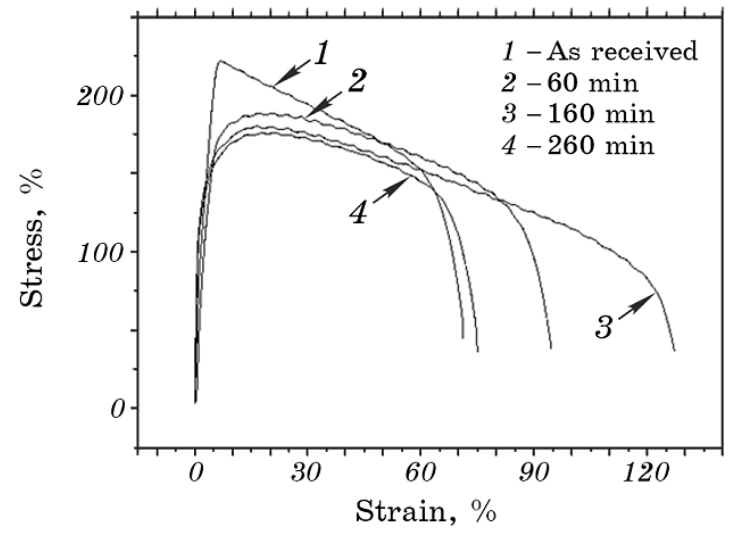

Fig. 6. Stress-strain diagrams for the samples tested at $800^{\circ} \mathrm{C}$. 
ing. Incomplete precipitation of carbides occurs during quenching after heat treatment, which increase the amount of free $\mathrm{C}$ in solution of the heat treated samples [34].

This cause more pronounced serrations in HT60, HT160, and HT260 compared to the as-received samples after testing at 500 and $800^{\circ} \mathrm{C}$. It was also observed that the magnitude of serrations decreased after increment in testing temperature from 500 to $800^{\circ} \mathrm{C}$. The more precipitation occurred in the samples tested at $800^{\circ} \mathrm{C}$ than samples tested at $500^{\circ} \mathrm{C}$. This cause less solute atoms in solution resulted in weak serrations in HT60, HT160 and HT260 samples compared to the as-received

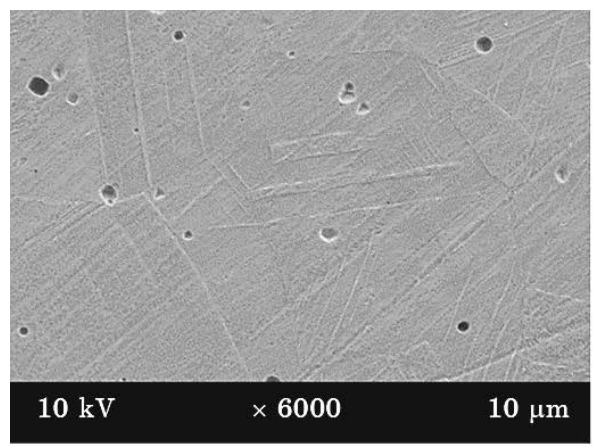

$a$

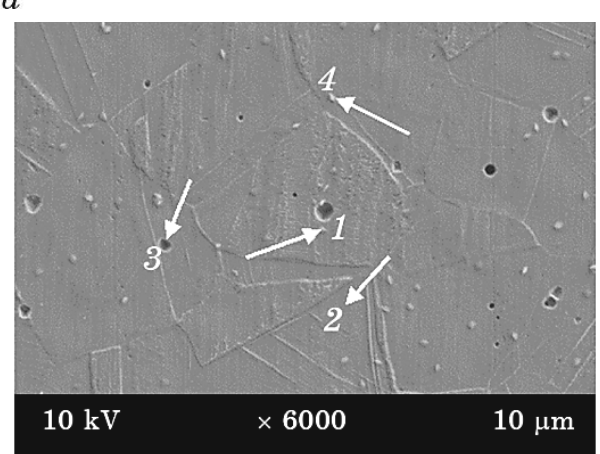

Mass percent, \%

\begin{tabular}{|c|c|c|c|c|c|c|c|c|}
\hline Spectrum & $\mathrm{C}$ & $\mathrm{Si}$ & $\mathrm{Ti}$ & $\mathrm{Cr}$ & $\mathrm{Mn}$ & $\mathrm{Fe}$ & $\mathrm{Ni}$ & Mo \\
\hline 1 & 0.34 & 0.08 & 1.29 & 19.30 & 3.85 & 74.57 & 0.25 & 0.31 \\
\hline 2 & 6.11 & 0.37 & 0.00 & 14.70 & 1.97 & 67.14 & 8.47 & 1.24 \\
\hline 3 & 0.00 & 0.22 & 0.93 & 18.39 & 3.17 & 77.03 & 0.00 & 0.25 \\
\hline 4 & 6.54 & 0.43 & 0.23 & 15.02 & 1.32 & 65.51 & 9.68 & 1.27 \\
\hline Mean value: & 3.25 & 0.28 & 0.61 & 16.85 & 2.58 & 71.06 & 4.60 & 0.77 \\
\hline Sigma: & 3.56 & 0.16 & 0.60 & 2.34 & 1.15 & 5.60 & 5.19 & 0.56 \\
\hline Sigma mean: & 1.78 & 0.08 & 0.30 & 1.17 & 0.57 & 2.80 & 2.60 & 0.28 \\
\hline
\end{tabular}

Fig. 7. SEM microstructure of as-received samples tested $a-25^{\circ} \mathrm{C}, b-500^{\circ} \mathrm{C}$, $c-800^{\circ} \mathrm{C}$, and $d-$ EDS analyse results of the samples tested at $800^{\circ} \mathrm{C}$. 
samples.

This is consistent with the SEM results as seen in Fig. 7 which shows SEM microstructures of HT60 samples. It is seen from Fig. 7 that more precipitates particles were observed in samples tested at $800^{\circ} \mathrm{C}$. Figure 7 also reveals EDS analysis with the different points marked on the microstructure of samples tested at $800^{\circ} \mathrm{C}$. As seen from Fig. 7 that
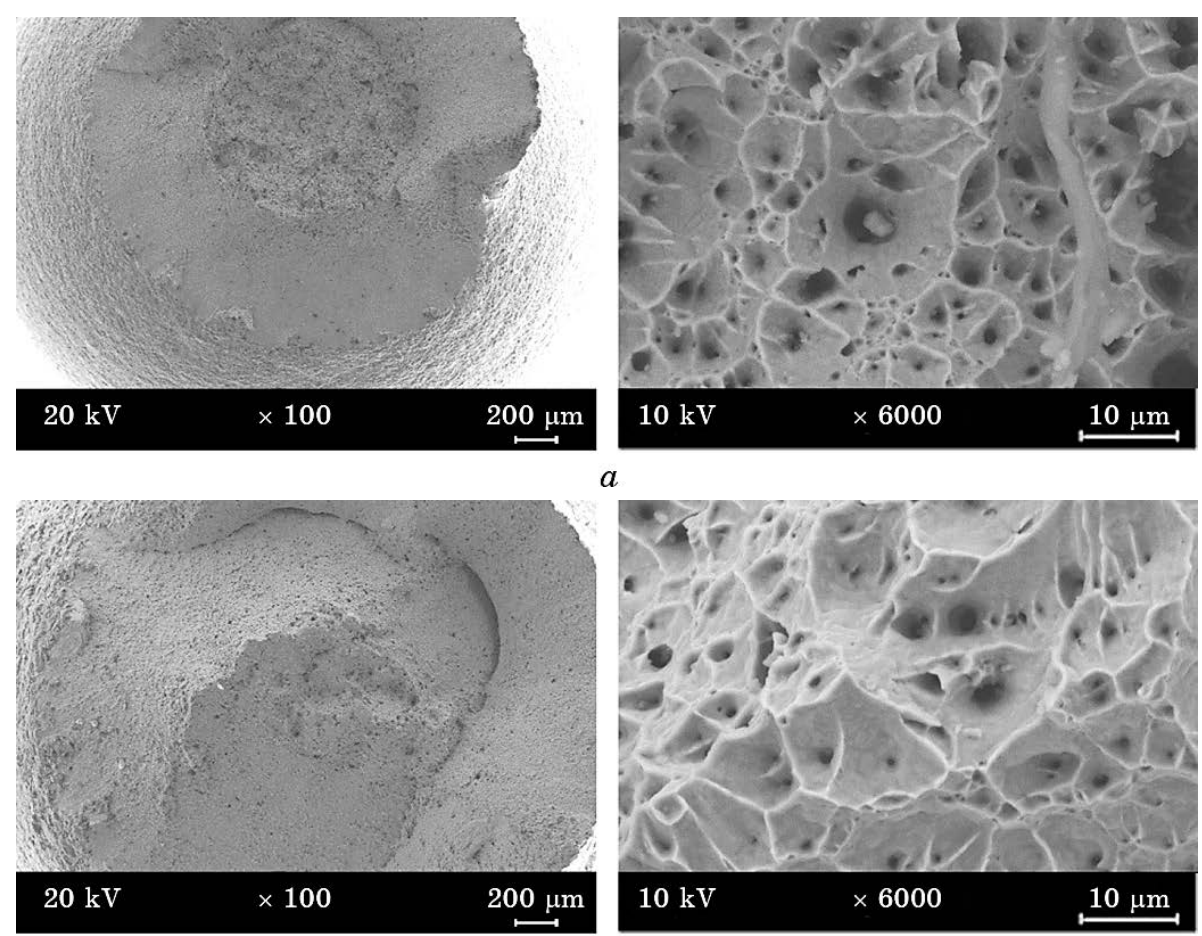

$b$
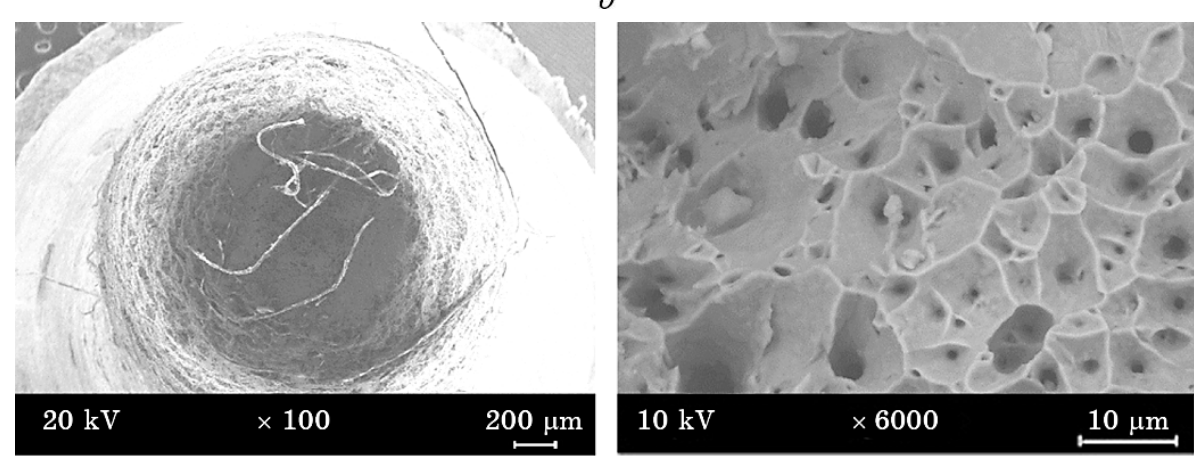

$c$

Fig. 8. Fracture surface of HT160 samples tested $a-25^{\circ} \mathrm{C}, b-500^{\circ} \mathrm{C}, c-$ $800^{\circ} \mathrm{C}$. 
points 2 and 4 contain $\mathrm{Fe}, \mathrm{C}, \mathrm{Cr}$ and Mo. These elements showed that (Cr, Mo) $\mathrm{C}$ are formed in HT60 sample after testing at $800^{\circ} \mathrm{C}$ in which the sample revealed weak serration behaviour.

The fracture surface of the broken tensile test specimens was examined using SEM. Figure 8 shows fracture morphology of the HT160 samples for the testing temperatures of 25,500 , and $800^{\circ} \mathrm{C}$. The fracture surface of HT160 samples tested at $25^{\circ} \mathrm{C}$ showed a dimpled structure which is indicative of a ductile fracture. This indicates a ductile fracture mode with the nucleation, growth and coalescence of microcavities [35]. At $500^{\circ} \mathrm{C}, \mathrm{HT} 160$ samples revealed cleavage facets and dimples. The reduction in area is also decreased at $500^{\circ} \mathrm{C}$ suggested that DSA occurred in HT160 samples. However, ductile dimples were observed in HT160 sample after testing at $800^{\circ} \mathrm{C}$, which increased the elongation and reduction in area. In addition, Fig. 8 shows that when the test temperature increased from $25^{\circ} \mathrm{C}$ to $500^{\circ} \mathrm{C}$ and $800^{\circ} \mathrm{C}$, fracture type changed from transgranular to intergranular fracture type. It is known that the fracture type of metallic materials changes from transgranular fracture to intergranular fracture type as the temperature increases [36]. In transgranular fracture, the cleavage planes or shear planes are weaker than the grain boundaries and the fracture occurs along the shear planes or cleavage planes within the grains. Intergranular fracture occurs along the grain boundaries due to weaker grain boundaries.

\section{CONCLUSIONS}

In this work, the effects of the deformation on mechanical properties of 316L ASS with different grain sizes were investigated. The cold, warm and hot deformation were carried out at temperatures of 25 , 500 , and $800^{\circ} \mathrm{C}$ for $1 \cdot 10^{-3} \mathrm{~s}^{-1}$ strain rate. The obtained results are as follows.

1. The microstructure of $316 \mathrm{~L}$ ASS consisted of austenitic structure with different grain sizes under as-received and heat treated conditions (HT60, HT160 and HT260). However, coarsening of austenite grains occurred when the samples were austenitised at $1100^{\circ} \mathrm{C}$ for 60 min (HT60), $160 \mathrm{~min}$ (HT160), and $260 \mathrm{~min}$ (HT260) and then cooled in water. Due to the rapid diffusion of atoms at high temperatures, grain growth has occurred because small grains tend to combine.

2. Ultimate tensile strength and flow stress at $3 \%$ of as-received, HT60, HT160 and HT260 samples tested at a deformation rate of $1 \cdot 10^{-3}$ $\mathrm{s}^{-1}$ showed a continuous decrease with increasing test temperature from $25^{\circ} \mathrm{C}$ to $500^{\circ} \mathrm{C}$ and $800^{\circ} \mathrm{C}$. It has been observed that the strength values decreased slightly in the range of $25-500^{\circ} \mathrm{C}$ but the tensile test performed over $500^{\circ} \mathrm{C}$ accelerated the decrease in strength values.

3. The elongation in 316L ASS falls gradually with increase in testing 
temperature to $500^{\circ} \mathrm{C}$ under as-received, HT60, HT160 and HT260 conditions. At above $500^{\circ} \mathrm{C}$, elongation of steel increased. Small variation in strength values and a decrement in elongation after testing $500^{\circ} \mathrm{C}$ indicated that DSA occurred in $316 \mathrm{~L}$ ASS under as-received, HT60, HT160 and HT260 conditions.

4. The increase in grain size in the as-received, HT60, HT160 and HT260 samples generally led to a decrease in ultimate tensile strength, flow stress at $3 \%$ and elongation values. The effect of grain size on strength was found to be reduced by increasing the test temperature to 500 and $800^{\circ} \mathrm{C}$. Increased grain size caused an increase in workhardening index $(n)$ values in contrast to the strength values. This indicates that more free $\mathrm{Cr}, \mathrm{C}$ or $\mathrm{N}$ atoms present in the grain with increasing grain size and effectively inhibit the movement of dislocations.

5. The fracture surface of the as-received, HT60, HT160 and HT260 samples showed transgranular fracture mode with microvoid morphology induced by dimple coalescence after testing at $25^{\circ} \mathrm{C}$. However, intergranular fracture mode with dimples and cleavage facets were observed at $500^{\circ} \mathrm{C}$. Further increase in testing temperature to $800^{\circ} \mathrm{C}$ resulted in intergranular fracture mode with more dimple pattern on the fracture surface of the as-received, HT60, HT160 and HT260 samples.

\section{ACKNOWLEDGMENTS}

This work was supported by Scientific Research Projects Coordination Unit of Karabük University. Project Number: KBU-BAP-18-YL-048.

\section{REFERENCES}

1. R.A. Lula, Stainless Steel (Ohio: American Society for Metals, Metals Park: 1986).

2. J. C. Lippold and D. J. Kotecki, Welding Metallurgy and Weldability of Stainless Steels (New Jersey: John Wiley\&Sons Inc.: 2005).

3. S. Kožuh, M. Gojić, and L. Kosec, Mater. Geoenvironment, 54, No. 3: 331 (2007).

4. Ren-bo Song, Jian-ying Xiang, and Dong-po Hou, J. Iron Steel Res. Inter., 18, No. 11: 53 (2011).

5. A. R. Ericson and R. E. Wiech, Metals Handbook (Materials Park, ASM Federation: 1994).

6. S. G. Chowdhury, S. Das, and P. K. De, Acta Mater., 53: 3951 (2005).

7. N. Solomon and I. Solomon, Revista Metal., 46: 121 (2010).

8. M. Naghizadeh and H. Mirzadeh, Metall. Mater. Trans. A, 49A: 2248 (2018).

9. G. Cios, T. Tokarski, A. Zywczak, R. Dziurka, M. Stepien, Ł. Gondek, M. Marciszko, B. Pawłowski, K. Wieczerzak, and P. Bała, Metall. Mater. Trans. A, 48A: 4999 (2017).

10. S. S. Satheesh Kumar, M. Vasanth, P. Ghosal, Vajinder Singh, and T. Raghu, J.Alloy. Compd., 699: 1036 (2017). 
11. F. Bottoli, G. Winther, T. L. Christiansen, K. Vinter Dahl, and

M. A. J. Somers, Metall. Mater. Trans. A, 47A: 4146 (2016).

12. F. Borgioli, E. Galvanetto, and T. Bacci, Vacuum, 127: 51 (2016).

13. Y. S. Kim, S. H. Bak, and S. S. Kim, Metall. Mater. Trans. A, 47A: 222 (2016).

14. K. Spencer, J. D. Embury, K. T. Conlon, M. Veron, and Y. Brechet, Mater. Sci. Eng. A, 387: 873 (2004).

15. D. R. Askeland, The Science and Engineering of Materials (UK, London: Chapman and Hall: 1996).

16. L. H. De Almeida, P. R. O. Emygdio, and I. Le May, Scr. Metall. Mater., 31: 505 (1994).

17. A. Gironès, L. Llanes, M. Anglada, and A. Mateo, Mater. Sci. Eng. A, 367: 322 (2004).

18. T. Gladman, The Physical Metallurgy of Microalloyed Steels (UK, London: Institute of Materials: 1997).

19. F. George and V. Voort, Grain Size Measurement, in: Practical Applications of Quantitative Metallography (PA, Philadelphia: ASTM Special Technical Publication 839: 1994).

20. G. A. Muhamed, S. Gündüz, M. A. Erden, and D. Taştemur, Metals, 7, No. 362: 2 (2017).

21. D. Taştemur and S. Gündüz, Mater. Res. Ibero-American J. Mater., 21, No. 1: 1 (2018).

22. G. Ananthakrishna, Phys. Rep., 440: 113 (2007).

23. C. Gupta, J. K. Chakravartty, and S. Banerjee, Int. J. Metall. Eng., 2, No. 2: 142 (2013).

24. T. Doğan and S. Gündüz, 2nd International Turkish World Engineering and Science Congress (November 7-10, Turkey, 2010).

25. X. Zhang, N. Hansen, Y. Gao, and X. Huang, Acta Mater., 60: 5933 (2012).

26. G. E. Dieter, Mechanical Metallurgy (New York: McGraw-Hill: 1988).

27. S. Gündüz, Ironmaking and Steelmaking, 29: 341 (2002).

28. H. Alihosseini and K. Dehghani, Mater. Sci. Eng. A, 549: 157 (2012).

29. C. F. Kuang, J. Li, S. G. Zhang, J. Wang, H. F. Liu, and A. A. Volinsky, Mater. Sci.Eng. A, 613: 178 (2014).

30. W. Alshalfan, J. Speer, D. K. Matlock, and K. Findley, Metall. Mater. Trans. A, 37: 207 (2006).

31. V. T. L. Buono, B. M. Gonzales, and M. S. Andrade, Scr. Mater., 38: 185 (1997).

32. S.-G. Hong and S.-B. Lee, Int. J. Fatigue, 26: 899 (2013).

33. Z. Huang, D. Wagner, and C. Bathia, Inter. J. Fatigue, 80: 113 (2015).

34. R. Kaçar and S. Gündüz, Kovove Mater., 47: 185 (2009).

35. W. D. Callister and D. G. Rethwisch, Materials Science and Engineering (New York: John Wiley and Sons: 2011).

36. E. S. Kayalı and C. Ensari, Metallere Plastik Şekil Verme Illke ve Uygulamaları [Plastic Forming Princibles and Applications for Metals] (İstanbul: İTÜ: 2000) (in Turkish). 